\title{
Vineyard's Cultural Landscape in Castilla-La Mancha (Spain): evolution and transformations
}

\begin{abstract}
The autonomous community of Castilla-La Mancha is the region with the biggest vineyard area of Spain. The rural landscape is totally adapted to the geographical conditions of the Mediterranean Europe, with signs of proper identity derived from its historical tradition and a peculiar way of working the territory by the population. Its natural dynamics and complexity, consequence of the capacity to adapt to social and economic processes which have conditioned it over time, is united to the importance of the agricultural structure. This work has the objective to analyse that kind of process with the analysis of the vineyard's historical evolution, transformations derived from the application of the Common Agrarian Policy of the European Union, and its undeniable cultural nature that means an interesting potential to contribute to the territorial development. Keywords

Vineyard landscape $\cdot$ Castilla-La Mancha $\cdot$ evolution $\bullet$ cultural landscape
\end{abstract}

(C) University of Warsaw - Faculty of Geography and Regional Studies

\author{
M. Carmen Cañizares ${ }^{1}$, \\ Ángel Raúl Ruiz Pulpón ${ }^{1}$ \\ ${ }^{1}$ Universidad de Castilla-La Mancha, Spain \\ e-mail:MCarmen.Canizares@uclm.es \\ e-mail:AngelRaul.Ruiz@uclm.es
}

Introduction: an approach to cultural farmlands

The new concept of territorial culture that we have assumed in Spain since the beginning of this century allows us to see it as "culture, history, collective memory, identity model, public property, a space of solidarity and legacy” (VV.AA. 2006, p 2), responding to a renewed view that allows us to regard territory and its landscapes more in terms of heritage. To this, we add that a landscape is defined as "any part of the territory, as the population perceives it, the nature of which is the result of the action and interaction of natural and/or human factors" according to the European Landscape Agreement (CE 2000), since it is easy to understand that certain socioeconomic activities, such as agricultural activities, shape clearly identifiable landscapes - the theme chosen in this case.

It was UNESCO that institutionally recognised the cultural nature of some exceptional landscapes in the world by classifying them since 1992 as cultural landscapes that "combined works of nature and of man", as designated in Article 1 of the World Heritage Convention in its $16^{\text {th }}$ session. They are illustrative of the evolution of human society and settlement over time under the influence of the physical constraints and/or opportunities presented by their natural environment and of successive social, economic and cultural forces, both external and internal. In addition, cultural landscapes often reflect specific techniques of sustainable land use, considering the properties and limits of the natural environment in which they are established and a specific spiritual relation to nature.

At the international level, this category initiated the international legal protection of cultural landscapes. These are classified as possessing "an exceptional universal value" and fulfilling one or more of the established criteria, which (subject to periodic revision) are: presenting a masterpiece of human creative genius (criterion I), bearing unique or at least exceptional testimony to a cultural tradition or to a civilization which is living or which has disappeared (III), or being an outstanding example of a traditional human settlement, land-use, or sea-use which is representative of a culture (or cultures), or human interaction with the environment, especially when it has become vulnerable under the impact of irreversible change (V) (Cañizares 2014, pp. 154-155). There is no doubt that it prints a very valuable "brand image" in the context of cultural industries and in relation to territorial development, as happens in: the coastal vineyards of Amalfi and Cinque Terre, both in Italy; French vineyards from the Saint Emilion jurisdiction in the Bordeaux area, and in vineyards of the Loire; in the vineyards of Alto Douro and Pico in Portugal; in German farmlands from the region of the Rhineland-Palatinate, where the vine is cultivated on the banks of the Rhine; in the Hungarian landscape of the Tokaj area; and in the terraced vineyards of Lavaux, Switzerland, among others included on the World Heritage List in the Cultural Landscapes category (Cañizares \& Ruíz 2014).

In Spain, since 2011, the Cultural Landscape Plan assumes the "cultural landscape" good as an object of the heritage policy and therefore incorporates values and heritage management on the territorial scale, thus contributing from a cultural perspective to the coordination and cooperation with other administrations (regional and local) (Cañizares 2017, p. 162). Although its definition of Cultural Landscape is close to that of UNESCO, it is not restricted to those with exceptional universal value but considers 
Table 1. Vineyard surface evolution (hectares) in Castilla-La Mancha (1857-1987)

\begin{tabular}{|c|c|c|c|c|c|c|c|}
\hline $1857^{1}$ & $1884^{1}$ & $1904^{1}$ & $1931^{2}$ & $1950^{2}$ & $1972^{2}$ & $1987^{2}$ & $\begin{array}{c}\text { Balance } \\
(1857-1987)(\%)\end{array}$ \\
\hline 142,367 & 186,000 & 305,634 & 400,901 & 481,187 & 599,881 & 717,295 & $+404 \%$ \\
\hline
\end{tabular}

Source: Rodríguez Tato (1), Spanish Agrarian Statistics Yearbook (2). Own Elaboration.

all landscapes from a cultural aspect. Among them, "agrarian, livestock and forestry" landscapes are included in the Plan, some of them linked with vineyards, others with industrial, infrastructure and commercial activities, as well as urban, historic, defensive and symbolic activities.

In this theoretical context, the objective of this study is to delve into the landscape determined by vine cultivation in the CastillaLa Mancha region (Spain) by an analysis of its historical evolution, the transformations derived from the European Union Common Agrarian Policy, and its cultural nature in terms of heritage wealth and potential to contribute to territorial development, such as through wine tourism (Plaza, Cañizares \& Ruíz 2017).

Evolution of vine cultivation in Castilla-La Mancha (Spain) and its effect on landscape

With close to 444,000 hectares in 2016, Castilla-La Mancha is the region with the largest area dedicated to vine cultivation in Spain. This number is $47 \%$ of the national total for vineyards, and the region's production of around 22.5 million hectolitres in the 2015/16 season constitutes $53.5 \%$ of the Spanish total. At the same time, it forms $13 \%$ of the area of the European Union and $8 \%$ of the world's production of wine and its by-products, which makes that area one of the major vineyards of the world in terms of spatial quantity. The structural importance of the exploitation is the result of a long historic evolution in which various social and economic factors took part, including the entry of Spain into the European Union as one of the key moments. We can differentiate up to four steps in the vineyard evolution. We can connect it, in general terms, with the succession of agrarian phases studied by Félix Pillet (2001) for regions such as La Mancha (Pillet 2001) and the last proposed periodisation (Cañizares \& Ruiz 2014), which is being updated based on structural changes related with farming modernisation and pathways derived from the approval of Common Organisation Market of wine.

\section{First stage: self-supply phase $\left(12^{\text {th }}\right.$ century to 1857$)$}

Despite the presence of amphorae, bowls and mud barrels from Pre-Roman and Roman ages in different regional settlements, such as the Cerro de Las Cabezas in Valdepeñas (Ciudad Real) or the Carranquevilla (Toledo), we do not have sufficient studies or sources to determine the significance of the vineyard in antiquity. Starting from the $12^{\text {th }}$ century, the vineyard started to expand slowly in Castilla-La Mancha due to repopulation by the Military Orders ${ }^{1}$, which forced people settling in their domains to cultivate them. The motives were mainly cultural, as wine played a key role in Christian liturgy and was used as containment against the arrival of Muslim settlers, and it was also economical, because the Orders ensured themselves a regular source of income from planting vineyards and selling wine outside their jurisdiction (Del Valle 2003). In the Modern Era (especially in the $16^{\text {th }}$ and $17^{\text {th }}$ centuries), the battle of interests between small farmers and members of the local aristocracy

\footnotetext{
${ }^{1}$ The Military Orders were institutions of a religious-military type charged with spreading and defending the Christian faith and strictly associated with the privileged classes (aristocracy and clergy). Notable in Castilla-La Mancha were the Orders of San Juan, Calatrava and Santiago.
}

determined the rate of propagation of the cultivation, being especially outstanding in municipalities such as Manzanares and Valdepeñas, located on the Camino Real, which linked the south with the centre of Spain (from Andalusia to Madrid). Despite its relative importance, the general agrarian structure was dominated by stockbreeding and cereals, while vineyards were located on marginal fields and almost exclusively oriented towards self-supply.

Second stage: expansion and overproduction (1857-1986) Starting from the second half of the $19^{\text {th }}$ century, vineyards in Castilla-La Mancha experienced an important expansion that extended to the entry of Spain into the European Economic Community in 1986. According to Table 1, the growth of the vineyard area between 1857 and 1987 was $404 \%$ in the area.

That impressive increase has its roots in the last quarter of the $19^{\text {th }}$ century, a moment in which a series of circumstances happened that explain the take-off of regional viticulture: the cereal prices crisis, the effects of phylloxera in France and the reinforcing of the regional road network (Pillet 2001).

From 1855, cereals from America were being introduced into Spain at prices that caused stiff competition for regional cereals (Rodríguez 1988). The most significant consequence was the gradual substitution of cereals with vines on low productivity plots, which was favoured by the vine's optimal edaphic and climatic adaptability and the economic possibilities opening up to small farmers. Those benefits paid off from 1868 onwards when the phylloxera ${ }^{2}$ plague started to affect French vineyards, thus boosting the demand for wine from nearby countries. The most significant result was the signing of the Franco-Spanish Commercial Treaty in 1882 allowing the entrance of Spanish wines into France thanks to a generalised duty fee reduction, which fostered a "golden age" for Spanish wine-making regions, especially Castilla-La Mancha, which became the main production area of Spain at the beginning of the $20^{\text {th }}$ century. The vine, which was a marginal crop at that time, became the strongest foundation of the regional economy thanks to its expansion and profitability.

The consolidation of the Manchegan vineyard was also due to other factors of an agronomic and economic type. In the first place, the influence of phylloxera in our region did not reach the same level of importance as in other Spanish regions such as Catalonia or the Region of Valencia at the beginning of the $20^{\text {th }}$ century. Secondly, demand from cities close to the Mediterranean Sea, the Cantabrian Sea and the capital itself, Madrid, together with the improvement of communication networks, especially railways, reinforced commercial relations. After the Spanish Civil War (1936-1939), vineyards secured by an agrarian structure achieved growth of more than 300,000 hectares from 1931 to 1987 , consolidating themselves as an authentic regional monoculture. The increased area and the high performance obtained favoured the appearance of the first problems of overproduction in the fifth decade of the $20^{\text {th }}$ century, an imbalance which would become the main distinguishing mark of Castilla-La Mancha's viticulture until the present day.

2Phylloxera is a vine disease caused by the insect Dactylosphaera vitifoliae. 
MISCELLANEA GEOGRAPHICA - REGIONAL STUDIES ON DEVELOPMENT

Vol. 22 • No. 2 • 2018 • pp. 90-94 • ISSN: 2084-6118 • DOI: 10.2478/mgrsd-2018-0007

Third stage: Regulation measures and generalisation of irrigation (1987-1999)

After the entry of Spain into the European Economic Community in 1986, the viticulture sector was exposed to market regulation mechanisms destined to palliate the structural excess problem. Among the suggested initiatives, the most noteworthy was the ultimate uprooting of vineyards as set out in the Regulation (EEC) 1442/88, which, thanks to subsidies around 7,000 ECUS per hectare resulted in the loss of more than 130,000 hectares of vineyard in Castilla-La Mancha by 1996, clearly reverting the previous upward trend.

Despite the total vineyard area decreasing, those measures of a punitive kind could not counter the increased productivity derived from the inclusion of irrigation, which underwent rapid expansion thanks to mainly internal factors. Added to the need to maximise the profitability of crops, there was at this time a period of Castilla-La Mancha drought in Spain that occurred between 1991 and 1995 and that forced administrations to lift the irrigation prohibition on that specific agricultural subsector in 1995. The result was the fast expansion of irrigated areas starting from that time onwards (Figure 1), with an estimate of more than 80,000 hectares in ten years (1996-2006).

In return, non-irrigated vineyard areas experienced a loss of more than 400,000 hectares between 1986 and 2016, explained by the withdrawal of low productivity vineyards, the influence of vineyard uprooting programmes and the generalised process of viticulture modernisation starting in 1999.

Current stage: Modernisation, competitiveness and postproductivism (1999-present)

The diffusion of irrigation was also possible thanks to the implementation of the Common Organisation of the Viticulture Market of 1999 (CMO). Since 1993, the European Commission had already been planning the productive adaptation of the main European producing regions in order to meet the pressure for new varieties of grapes in greater demand in the markets. The new varieties, mainly of Atlantic origin, required extra water which, as a consequence, was an incentive to increase irrigation.

That process of adapting was achieved thanks to the reorganising and varietal restructuring programmes approved in 2000, which had important effects on the landscape by the generalising of new vine varieties and the appearance of vineyards in espalier.

Varietal diversification is linked to those who encouraged the administration in recent years. According to the data offered by the regional administration, between 2000 and 2007 a profit of $3.1 \%$ was confirmed from red grape varieties, notably Cencibel or Tempranillo, already forming $17.5 \%$ of the total extents in 2010 , together with other varieties that were barely known in CastillaLa Mancha, such as Syrah and Cabernet Sauvignon. However, there was a yearly decrease of $2.6 \%$ in the traditional white variety airén, to the point of currently reaching only $47.5 \%$ of the regional viticulture area.

Secondly, the aids granted to the mechanising of agrarian activities explain the emergence of a new type of viticulture landscape: vineyards in espalier. From the 467,000 hectares of vineyards in Castilla-La Mancha at the time of launching the vine in 2008 by the CMO, $17.2 \%$ were already in that category.

The expansion of vineyards in espalier (Figure 2) generated new social and economic dynamics in the territory. Generally, it is a type of vineyard that involves a more intensive use of the soil while incorporating, almost in a generalised way, support watering that obviously improves the performance of the exploitation and allows the important costs of the initial investment and of production to be tackled.

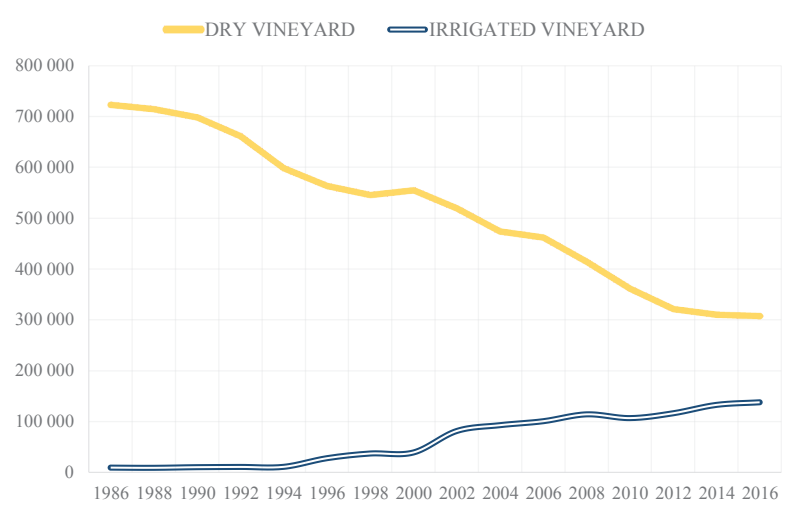

Figure 1. Vineyard surface evolution: Dry and irrigated vineyard (hectares)

Source: elaboration based on the Agricultural Statistics

Yearbooks of the MAPA (Spain).

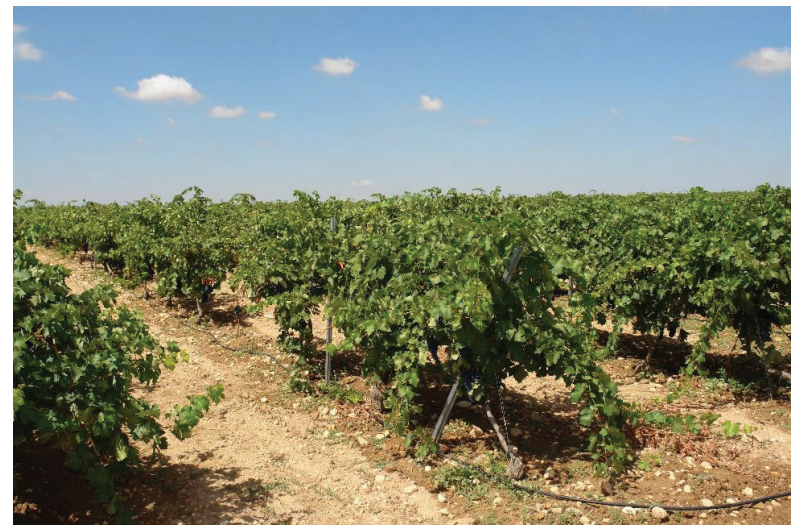

Figure 2. Vineyard in espalier (Socuéllamos, Castilla-La Mancha, Spain)

Source: Ángel Raúl Ruiz Pulpón

The use of water implied a new factor of environmental pressure on aquifers in the zone, in particular on the Occidental Mancha aquifer, which was officially overexploited by the administration, thus confirming the absence of the integration of sectoral policies that intervene in the territory.

Those reorganising and varietal restructuration programmes were extended in the Regulation (EC) 479/2008 of the Council of 2 April, which set a new CMO for the viticulture sector. Generally, it is calculated that what follows is an improvement of the viticulture sector on the basis of the development of competitiveness, modernisation and commercialisation, these being important measures linked to the regulation of the productive potential. Among some of them, the prohibition on creating new crops of vine until 31 December 2015 and the fixing of a bonus for uprooting vineyards during three seasons (2008/09, 2009/10, 2010/11) stands out, justified as a complementary measure aimed at the adapting of productive zones especially when they did not assure a viable production. The first results of that programme showed that Spain represented $58 \%$ of the total vineyards uprooted in the European Union during the period, meaning a reduction of the productive potential of around $43 \%$. In Castilla-La Mancha, a total of 77,247 hectares were uprooted, that is, $82 \%$ of the national area and $47 \%$ of the total area uprooted in Europe. That exaggerated indicator showed that Castilla-La Mancha did not enjoy such a 

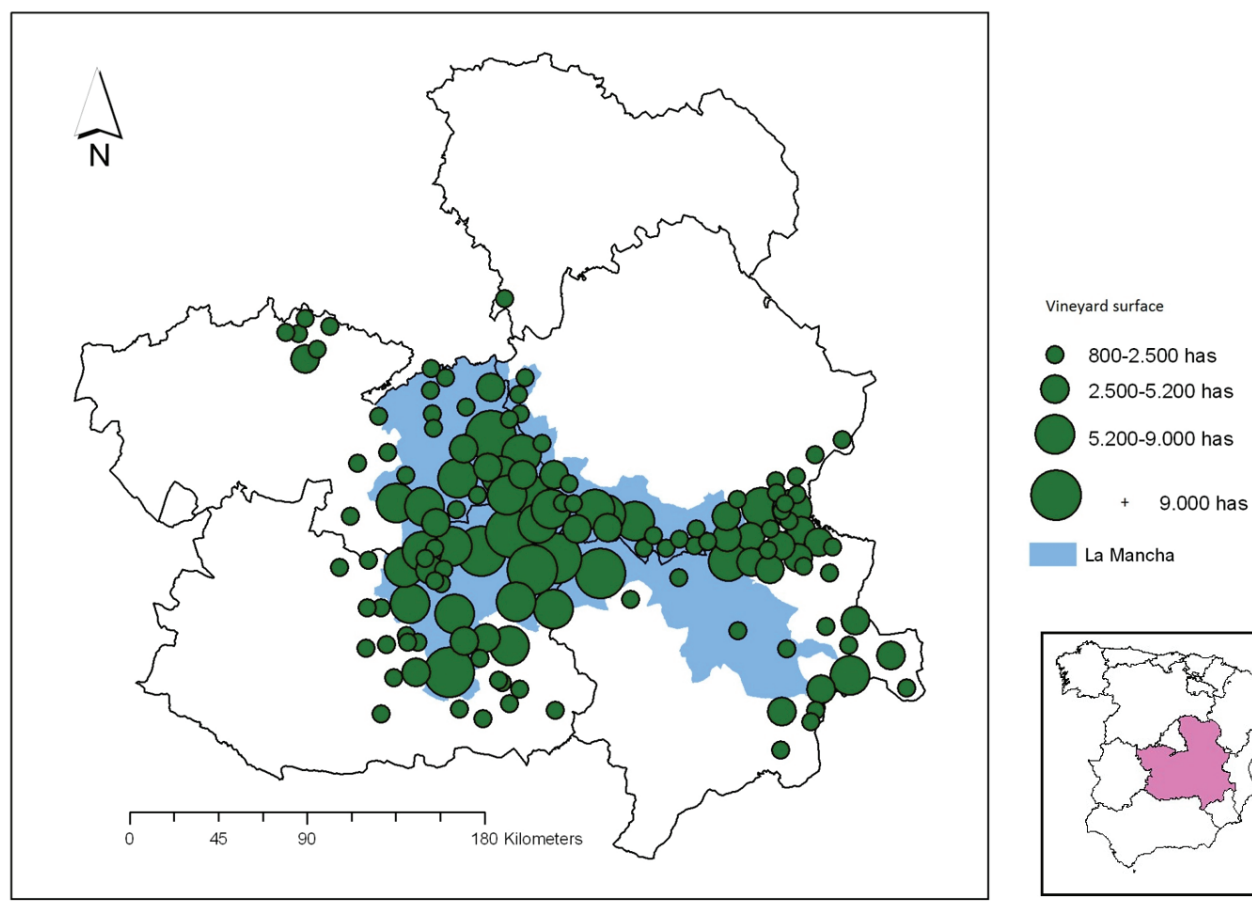

Figure 3: Vineyard area in Castilla-La Mancha (Spain)

Source: Ángel Raúl Ruiz Pulpón and Regional Goverment of Castilla-La Mancha (2015)

consolidated position in the market as other Spanish productive regions such as Galicia and La Rioja, neither of which saw the need to join that kind of programme. These strictly productive and neoliberal types of dynamics are contrasted by non-productive aspects of the vineyard, such as heritage, environmental and cultural values that can be interpreted within the controversial concept of "post-productivism" that we will explain below.

The vineyard in Castilla-La Mancha (Spain) and its valuation as cultural landscape

If any landscape is by definition "cultural," it is a result of the interaction between society and nature, or how mankind adapted to a given environment and transformed it to survive within it. The lanscape generated by the cultivation of the vine in the region of Castilla-La Mancha over time presents a clearly identifiable cultural dimension closely related to the material and immaterial heritage it contains. According to the definition of the National Plan of Cultural Landscape in its last review (2015), a "cultural landscape" is "the result of the interaction between persons and the natural environment over time, which is expressed as: a territory perceived and valued for its cultural qualities; a product resulting from a process; and support for the identity of a community" (IPC 2015, p. 25), which we also can identify as a Heritage Landscape since it is of special cultural interest, deserving recognition and protection for its high values (Silva, Fernández Salinas \& Mata 2017, p 17).

Special features of the vineyard landscape in Castilla-La Mancha (Spain)

If today we consider the landscape as a "territorial and historic totalling" (Silva, Fernández Salinas \& Mata 2017, p. 19), that of the Castilla-La Mancha vineyards reflects the changes that have continued over time, the difficulties of adapting to community policies and how it still is a model of identity for the local population. The special features that allow us to analyse its nature are:
- It is an historic landscape (cultural) whose roots date back, as we indicated, to the Romanisation in the Iberian Peninsula.

- It is the result of a specific physical environment (especially the Manchegan grassland) and some capacities of transforming that environment by mankind, defined at present as the reality of an agribusiness sector dedicated to production, transformation and commercial distribution.

- From an aesthetic point of view, it is a landscape transmitting harmony and beauty, as reflected by diverse writers and painters throughout the decades.

- It defines a clear element of identity for local populations for whom that cultivation is the main way of life.

- From a social point of view, it means an exploitation upon which a solid cooperative fabric is organised, being a key factor for territorial support.

- It incorporates distinctive commercial strategies. On the one hand, we have the traditional commercial output from wine and grape juice sales in bulk, carried out by means of commodities, with low prices and large quantities to any kind of market; on the other hand, we look for the creation of quality bottling wines.

- Castilla-La Mancha is the Spanish region with the most distinctive quality processed foods associated with wine as a result of the structural importance of that agrarian use; that importance is reflected in it being one of the first Spanish regions to have protected any viticulturist under a $\mathrm{PGI}^{3}$ (Wines of Castilian Soil in 1999).

From a post-productivist perspective, vineyard landscapes combine some associated values such as the development of wine tourism, commitment to quality, and appreciation of landscape values.

\footnotetext{
${ }^{3}$ Protected geographical indication
} 
Resources from the agrarian heritage in vineyard landscapes

The elements (resources) of Agrarian Heritage in the vineyard landscapes of Castilla-La Mancha can be grouped following the Charter of Baeza on Agrarian Heritage (ed. Castillo 2013). Initially, they were grouped within material heritage as: goods or implements and tools (jars, sheds, squeezers, etc.), elements linked to transport (various types of carts, wagons, etc.) and bibliographical documents and objects (literary texts from authors such as Cervantes, Antonio Ponz, Francisco Nieva, etc.); singular real estate, above all of a structural type (wine cellars, farmhouses, shacks, etc.); and equal and grouped real estate, such as the wine landscapes themselves (especially those of the traditional vineyard), population settlements, livestock paths and routes (the Sorian and Segovian royal cattle route). In immaterial heritage we differentiate between: language (singular terms associated to wine culture, such as "viñuelo" or "atroje", a collection of popular proverbs about wine, etc.); beliefs, rituals and festive acts (Romería de la Virgen de las Viñas in Tomelloso, etc.); and wisdom, works and traditions (forge, cutlery, traditions associated with grape harvesting, etc). To all that we add a natural and genetic heritage based on: some physical properties of the territory associated with prairies and plains (average altitude 650 $\mathrm{m}$ ); extreme climate and limited rainfall (under $400 \mathrm{~mm}$ yearly) with regular droughts, optimally clayey soil for vine cultivation, a high number of sunlight hours during the year; and a varietal genetic contribution centred on the Cencibel or Tempranillo grape for the red wines and on the airén grape for the white (Cañizares \& Ruiz 2014). Everything that defines "heritage vectors", that is, elements forming landscapes that possess an identity value attributed to the local population or that have obtained institutional recognition (Silva, Fernández Salinas \& Mata 2017, p 21) and that are fundamental to the process of heritage recognition.

\section{Conclusions}

Every landscape settled by man is, by definition, cultural, and is a demonstration of the history of a territory. The strengths of vineyard landscape potential lie in its large expansion and its economic efficiency, which will support the survival of heritage resources or its tourist exploitation. But there are also less favourable aspects related to the search for high efficiency and the adopting of new methods and techniques (substitution of vineyards in cup shape for the ones in espalier) derived from the CAP (Common Agricultural Policy) and the modernisation of production. There are also unfavourable aspects related to the scant institutional attention being dedicated to the conservation of an agrarian heritage that show signs of the imperilment of the legacy of local memory, identity and people connected with the cultivation of the vineyard. The largest European vineyard needs to promote measures devoted to awareness and full conservation of this cultural landscape, and in particular to landscape conservation and protection policies.

\section{References}

Cañizares, MC 2014, 'Paisajes culturales, ordenación de territorio y reflexiones desde la Geografía en España', Polígonos. Revista de Geografía, no. 26, pp. 147-180.

Cañizares, MC 2017, 'Cultural landscapes and planning in Spain' in Territorial heritage and spatial planning. A geographical perspective, eds F Manero \& JL García Cuesta, Thomson Reuters Aranzadi, Pamplona, pp. 143-173.

Cañizares, MC \& Ruiz, AR 2014, 'Evolución del paisaje del viñedo en Castilla-La Mancha y revalorización del patrimonio agrario en el contexto de la modernización', Scripta Nova. Revista Electrónica de Geografía y Ciencias Sociales, 20XII2014, vol. XVIII, no. 498. Available from: <http://www. ub.es/geocrit/sn/sn-498.htm>. [29 November 2017].

Castillo, J (ed.) 2013, Carta de Baeza sobre el Patrimonio Agrario, UNIA, Sevilla. Available from: <http://www.unia.es/ explorar-catalogo/item/carta-de-baeza-sobre-patrimonioagrario>. [30 November 2017].

CE (Consejo de Europa) 2000, Convenio Europeo del Paisaje, Estrasburgo. Available from: <http://www.mapama.gob.es/ en/desarrollo-rural/temas/desarrollo-territorial/convenio. aspx>. [30 November 2017].

Del Valle, AR 2003, 'Las Órdenes Militares y el viñedo en Castilla-La Mancha', Cuadernos de Estudios Manchegos, no. 27, pp. 11-36.

IPC (Instituto del Patrimonio Cultural de España) (ed.) 2015, Plan Nacional de Paisaje Cultural, Ministerio de Educación, Cultura y Deporte, Madrid. Available from: <http://www. mecd.gob.es/planes-nacionales/dms/microsites/cultura/ patrimonio/planes-nacionales/textos-planes-nacionales/05maquetado-paisaje-cultural.pdf>. [1 December 2017].
Plaza, J, Cañizares, MC \& Ruíz, AR 2017, 'Patrimonio, viñedo y turismo: recursos específicos para la innovación y el desarrollo territorial de Castilla-La Mancha', Cuadernos de Turismo, no. 40, pp. 547-571.

Pillet, F 2001, La Mancha: transformaciones de un espacio rural, Celeste Ediciones, Madrid.

Rodríguez, MA 1988, 'El desarrollo del monocultivo vitivinícola en Castilla-La Mancha (1875-1900)', in I Congreso de Historia de Castilla-La Mancha, vol. 9, Junta de Comunidades de Castilla-La Mancha, Toledo, pp. 357-365

Silva, R, Fernández Salinas, V \& Mata, R 2017, 'Concepto, ámbito y significado de los paisajes patrimoniales' in Paisajes Patrimoniales de España, eds $\mathrm{F}$ Molinero, Ministerio de Agricultura y Pesca, Alimentación y Medio Ambiente, Madrid, pp. 13-34.

VV.AA. 2006, Manifiesto "Por una nueva cultura del Territorio". Available from: <http://www.geografos.org/images/stories/ interes/nuevacultura/manifiesto-por-una-nueva-cultura-delterritorio-d5.pdf>. [1 December 2017]. 